\title{
Factors Influencing the Growth of Farmers' Markets in Indiana
}

\author{
Christa Hofmann ${ }^{1}$ \\ Department of Agricultural Economics, Purdue University, West Lafayette, \\ IN 47907
}

\author{
Jennifer H. Dennis ${ }^{2,3}$ \\ Purdue University, Horticulture \& Landscape Architecture, 625 Agriculture \\ Mall Drive, 320 Horticulture Building, West Lafayette, IN 47906
}

\author{
Maria Marshall ${ }^{2}$ \\ Agricultural Economics, Purdue University, West Lafayette, IN 47907
}

Additional index words. farmers' markets, market organizers

\begin{abstract}
Nationally, the number of operating farmers' markets has increased $111 \%$ from 1755 markets in 1994 to 3706 in 2004. Indiana's farmers' markets have increased at double the rate in the same timeframe. An Internet and mail census was sent to market managers to assess operational procedures and factors that influence customer and vendor participation in the market. A two-stage least squares model was estimated for the vendor and customer model. Paying fees and the number of customers present were the two variables that had a significant, positive influence on vendor participation. The presence of WIC, number of products available, the absence or presence of live music, absence or presence of cooking demonstrations, and number of vendors were significant for the customer model. The absence or presence of concession stands and picnic areas was significant at the 0.10 level in the customer model.
\end{abstract}

In 2006, the U.S. Department of Agriculture (USDA) estimated farmers' markets to be a $\$ 1$ billion industry (Shaffer and Cox, 2006). Farmers' markets offer unique economic and social benefits to producers, consumers, communities, and the national food system (Gale, 1997). Producers are provided with an outlet for the food they produce and consumers are provided access to fresh, local products as well as a chance to build relationships with the farmers who grow their food. Communities benefit from agricultural diversity, which reduces economic risks associated with the loss of farmland. Farmers' markets boost the economy by providing the community with excitement and activity in downtown areas and local neighborhoods (Gale, 1997).

Indiana's farmers' markets have experienced tremendous growth. The number of Indiana farmers' markets reported in 1994 was 24 (USDA, 2006). In 2004, the number of markets in Indiana grew to 77, an increase of $222 \%$ within a 10 -year period (Wilmont, 2006). Nationally, the number of operating farmers' markets has increased $111 \%$ from 1755 in 1994 markets to 3706 in 2004 (Agricultural Marketing Service, 2006). The USDA reported that in 2000, 19,000 farmers used farmers' markets as their sole marketing

Received for publication 1 Feb. 2008. Accepted for publication 22 Apr. 2008.

${ }^{1}$ Former graduate student.

${ }^{2}$ Assistant Professor.

${ }^{3}$ To whom reprint requests should be addressed; e-mailjhdennis@purdue.edu. outlet (Payne, 2000). Farmers' markets have been an attractive outlet for small farm operators, those with less than $\$ 250,000$ in annual receipts (USDA, 2006), because the market provides a larger product offering and customer base than a farmer could provide alone. Small farms capture higher margins from the market by recovering markup costs that would otherwise go to an intermediary such as a wholesaler or distributor. The increase in the number of farmers' markets and customer patronage has been a reflection of consumer demand for fresh produce in recent years (Gale, 1997). Consumers have been looking for more distinct products (i.e., organic, product of U.S. and local) and local has been one of the niches that provides the answer (Severson, 2006).

\section{Farmers' Markets Organizational Structure}

Market masters or managers (from this point forward, the term "market master" and "market manager" are used interchangeably) are responsible for the daily operation and supervision of each market. This individual may be a city employee, market vendor, or volunteer. The market master serves as a liaison between the market and other local businesses and coordinates the advertising, promotional activities, and public relations for the market. The market master works with vendors and collects registration forms, proof of insurance, and booth fees.

A vendor is anyone who has items for sale at the farmers' market. The planning committee or board of directors is responsible for setting guidelines for the products that may be sold at the market. A vendor may be a farmer, horticulturist, baker, food processor (e.g., jelly, salsa, and relish), crafter, or artisan.

A model for successful farmers' markets. Farmers' markets have been used to rebuild local economies and to connect local producers with consumers. O'Neil (2005) and the New York Farmers' Market Federation (NYFMF, 2005) defined 10 qualities necessary to make a successful market. Their lists were combined into six key attributes: 1) location; 2) product mix; 3) effective management; 4) market planning; 5) affordable rent; and 6) community involvement. Although Indiana's farmers' markets have grown at twice the rate of the nation's markets, the factors that influence vendor and consumer participation in such markets are unknown. For example, high turnover of market masters decreases the consistency of the markets, which in turn may cause consumers and vendors to decrease their participation. Thus, the purpose of this study is to examine factors that influence vendor and customer participation at Indiana's farmers' markets.

\section{Materials and Methods}

In Fall 2006, an Internet and mail census was sent to market masters to assess operational procedures and factors that influence customer and vendor participation in the market. Following Dillman (2000), a letter was first sent from Purdue University's Department of Agricultural Economics and the Indiana State Department of Agriculture (ISDA) informing market masters that the census was available to download from the ISDA web site. Seventy-seven farmers' markets were identified in Indiana from a USDA list (USDA, 2006). Because the targeted population was finite and little information had previously been collected, all known farmers' markets were included in the census (Churchill and Iacobucci, 2002). A questionnaire was subsequently sent to the farmers' market manager, the individual responsible for the organization, daily operation, and supervision of the farmers' market. The market masters were asked to download the survey from the ISDA web site and fax or mail their completed responses to the Agricultural Economics Department in care of the researchers. Forty-three responses were received. After the data were cleaned, 36 observations were usable. Nonusable responses were a result of new markets that did not have operating information for 2006 and several on-site farm markets that were not eligible to complete the survey based on the farmers' market definition. In Dec. 2006, the USDA released an updated contact list for Indiana's farmers' markets. The updated list did not provide any new farmers' market locations. However, it did provide updated contact information for market masters. After deleting the markets who responded from the first mailing and including the updated information, a second mailing was sent on 8 Jan. 2007 
in an attempt to increase the number of responses. A second mailing, which included the questionnaire and a postage paid envelope, was sent to 44 market organizers. Eighteen responses were returned. After cleaning the data, 13 were usable. Overall, 80 farmers' market masters were contacted. Sixty-one responses were received for a response rate of $76.3 \%$. After removing unusable questionnaires, 49 responses remained for a final response rate of $61.3 \%$.

\section{Results}

Market masters ranged in age from 29 to 83 years with a mean age of 52 years. Approximately $54 \%$ were female; $100 \%$ were white; $83 \%$ had an education beyond a high school diploma; and more than half $(63.9 \%)$ of the market masters had an individual annual income of less than $\$ 40,000$.

The census found farmers' market masters were employed by a variety of entities. Eight market masters claimed multiple employers by checking more than one type of employment on the questionnaire. Approximately $29 \%$ of the responses were volunteers followed by $26.3 \%$ who served as both a vendor and market master. Market masters on average had 5 years of experience with a range of 1 to 20 years.

Vendor and customer participation. Two models were designed to examine variables that influence vendor and customer participation at farmers' markets and estimated using two-stage least squares regression. Two-stage least squares is used when variables within a regression are considered interdependent. Thus, because vendors attract customers and customers attract vendors, the models have an endogeneity issue. Therefore, the appropriate analysis would be a twostage least squares model.

With two-stage least squares, a consistent estimator of the structural parameters of an identified equation in a simultaneous system can be found (Griffiths et al., 1993). In Stage 1 , we estimate the reduced form parameters, $\pi_{\mathrm{i}}$, for each endogenous variable (vendors and customers) by $\hat{\pi}_{i}=\left(X^{\prime} X\right)^{-1} X^{\prime} Q_{i}$. We then use the estimates of the reduced form parameters to predict the sample values of $\hat{Q}_{i}$, where $\hat{Q}_{i}=X\left(X^{\prime} X\right)^{-1} X^{\prime} Q_{i}=X \hat{\pi}_{i}$. We then replace the right-hand side endogenous variables with the instrumental variables, $\hat{Q}_{i}$, and specify the statistical model as $Q_{i}=\hat{M}_{i} \delta_{i}+\bar{e}_{i}$. $X$ denotes a vector of exogenous variables and $M$ denotes a vector of both the endogenous variable and the other exogenous variables. In Stage 2, the statistical model is $Q_{i}=$ $\hat{M}_{i} \delta_{i}+\bar{e}_{i}$ where the correlation between $\hat{M}_{i}$ (the endogenous and exogenous variables) and $\bar{e}_{i}$ disappears. Therefore, in both the vendor and customer models that follow, the customer and vendor variables are the instrumental variables resulting from the first stage. The two-stage least squares models were analyzed using SAS software, Version 9.1 of the SAS System for Windows (Copyright (C) 2002-2003 SAS Institute Inc. SAS and all other SAS Institute Inc. product or service names are registered trademarks or trademarks of SAS Institute Inc., Cary, NC.).

The vendor model. The vendor model examines factors that influence vendor participation at farmers' markets. The dependent variable was the number of vendors that would participate at a select market for the 2006 season (Eq. 1)

$$
\begin{aligned}
\text { No. of vendors }= & \beta_{0}+\beta_{1} \text { years operating } \\
& +\beta_{2} \text { rules }+\beta_{3} \text { pay }+\beta_{4} \text { No. } \\
& \text { of customershat }+\beta_{5} \text { No. of } \\
& \text { services }+\beta_{6} \text { Reason } 1 \\
& +\beta_{7} \text { Reason } 2+\epsilon
\end{aligned}
$$

The independent variables included the number of years the market had been operating as of 2006. The second variable, "rules," was a dummy variable that was assigned a 1 if a set of bylaws or market rules existed and a 0 if the answer was no. "Pay" was the third dummy variable that assessed whether vendors were charged to participate in the market. If payment was required, the market was assigned a 1 ; if payment was optional or vending was free, the market was assigned a 0 . The fourth variable, "number of customers," was measured per week and was count data. The number of customers per week for 2006 ranged from 15 to 1000 . The fifth variable was "number of services." Market masters were asked to identify from a list which services were present at their farmers' markets. Services included public restrooms, picnic area(s), handwashing facilities, petting zoo, concession stand(s), live music festi$\operatorname{val}(\mathrm{s})$, and cooking demonstration(s).

The sixth and seventh variables, Reason 1 and Reason 2, were dummy variables. Market masters were asked to specify the primary reason for the market's existence from these three options: 1) to offer customers access to local products; 2) to provide farmers an outlet for their products; or 3) to bring economic activity to the area. Each reason was coded into a separate dummy variable called Reason 1, Reason 2, and Reason 3. If the market master identified Reason 1, the variable was coded as 1 and all other reasons were coded 0 . The Reason 1 and 2 variables were measured against the Reason 3 variable, which was included in the intercept, $\beta_{0}$. Descriptive statistics are shown in Tables 1 and 2 .

Each independent variable in Eq. 1 is expected to have a positive relationship with the dependent variable (number of vendors) except for the "pay" variable. The variables "years operating" and "rules" both contribute to the stability of the market (Marr and Gast, 1989; NYFMF, 2005; O'Neil, 2005). As the age of a business increases, the chance for failure decreases. Rules provide a structure for daily operations and reflect the mission of the market (NYFMF, 2005). Marr and Gast (1989) found that markets often fail as a result of a lack of rules or organizational structure. Because at least $30 \%$ of

\begin{tabular}{|c|c|c|}
\hline Reason for existence & Frequency & $\overline{\text { Proportion }}$ \\
\hline Consumers & 31 & $68.9 \%$ \\
\hline Producers & 6 & $13.3 \%$ \\
\hline Economic activity & 8 & $17.8 \%$ \\
\hline \multicolumn{3}{|l|}{ Years of operation } \\
\hline $1-5$ & 23 & $47.9 \%$ \\
\hline $6-10$ & 10 & $20.8 \%$ \\
\hline $11-20$ & 7 & $14.6 \%$ \\
\hline $21-30$ & 1 & $2.1 \%$ \\
\hline $31-40$ & 3 & $6.3 \%$ \\
\hline More than 40 & 4 & $8.3 \%$ \\
\hline Vendors & $\begin{array}{c}\text { Mean } \\
21.52\end{array}$ & $\begin{array}{c}\text { SD } \\
\pm 13.22\end{array}$ \\
\hline Customers & $\begin{array}{l}\text { Mean } \\
269.62\end{array}$ & $\begin{array}{c}\text { SD } \\
\pm 270.42\end{array}$ \\
\hline Rules or bylaws & Frequency & Proportion \\
\hline Yes & 42 & $85.7 \%$ \\
\hline No & 7 & $14.3 \%$ \\
\hline \multicolumn{3}{|l|}{ Day of operation ${ }^{2}$} \\
\hline Sunday & 1 & $1.4 \%$ \\
\hline Monday & 2 & $2.8 \%$ \\
\hline Tuesday & 9 & $12.5 \%$ \\
\hline Wednesday & 12 & $16.6 \%$ \\
\hline Thursday & 7 & $9.7 \%$ \\
\hline Friday & 3 & $4.2 \%$ \\
\hline Saturday & 38 & $52.8 \%$ \\
\hline $\begin{array}{l}\text { Hours of operation } \\
\text { (in hours) }\end{array}$ & Mean & SD \\
\hline Sunday & 3.00 & \\
\hline Monday & 2.75 & \pm 0.00 \\
\hline Tuesday & 4.67 & \pm 1.87 \\
\hline Wednesday & 3.96 & \pm 1.62 \\
\hline Thursday & 4.43 & \pm 2.28 \\
\hline Friday & 4.67 & \pm 2.08 \\
\hline Saturday & 4.46 & \pm 1.13 \\
\hline \multicolumn{3}{|l|}{ WIC FMNP } \\
\hline Yes & 34 & $70.8 \%$ \\
\hline No & 14 & $29.2 \%$ \\
\hline Pay & Frequency & Proportion \\
\hline Yes & 36 & $78.3 \%$ \\
\hline No & 10 & $21.7 \%$ \\
\hline
\end{tabular}
vendors use farmers' markets as their sole
Table 1. Demographic and operational characteristics of Indiana's farmers' markets reported by market master respondents.

${ }^{2}$ More than one response is allowed.

WIC FMNP = Women Infant \& Children Farmers' Market Nutrition Program.

marketing outlet, it is important that the market is a stable outlet for their products (Payne, 2000).

The expected relationship between pay and the number of vendors is unknown. The amount of money paid in fees is something vendors evaluate before participating in the market, but rarely is the cost high enough to discourage participation in the market. The fees collected allow markets to enhance their operation as well as to cover the cost of rent, insurance, advertising, promotion, permits, manager salary, and any other expenses incurred (NYFMF, 2005). The amount of the fees often shows the sophistication of the market because markets that charge more tend to have more money budgeted for advertising and promotion, whereas the markets that do not charge struggle to exist (NYFMF, 2005). Restrooms, handwashing facilities, picnic areas, and concession stands provide services not only to customers, but also to vendors. Markets exist for three primary reasons: customers, vendors, or economic revitalization; each reason should promote and attract vendors. 
Table 3 contains the estimated coefficients, SEs, and t-values for the vendor model. The adjusted $R^{2}$ for Eq. 1 was $43 \%$ indicating a good fit. The variables pay and number of customers were positive and statistically significant at the 0.01 and 0.05 levels, respectively. Pay is a dummy variable in which an incurred cost to vend at the market was coded 1 and 0 if no fees were paid. The estimated coefficient of number of customers is 0.0873

Table 2. Products and services provided at Indiana's farmers' markets.

\begin{tabular}{|c|c|c|}
\hline & $\begin{array}{c}\text { Frequency } \\
\text { (yes) }\end{array}$ & Percentage \\
\hline \multicolumn{3}{|l|}{ Products } \\
\hline Vegetables & 49 & $100.0 \%$ \\
\hline Fruits & 47 & $95.9 \%$ \\
\hline Cut flowers & 44 & $89.8 \%$ \\
\hline Bedding plants & 42 & $85.7 \%$ \\
\hline Herbs & 41 & $83.7 \%$ \\
\hline Honey & 41 & $83.7 \%$ \\
\hline Organic produce & 37 & $75.5 \%$ \\
\hline $\begin{array}{l}\text { Baked goods } \\
\quad \text { (breads, pastries) }\end{array}$ & 35 & $71.4 \%$ \\
\hline Eggs & 34 & $69.4 \%$ \\
\hline $\begin{array}{l}\text { Freezer meat } \\
\text { (beef, elk) }\end{array}$ & 31 & $63.3 \%$ \\
\hline $\begin{array}{l}\text { Processed foods } \\
\text { (relish, salsa) }\end{array}$ & 31 & $63.3 \%$ \\
\hline Jams and jellies & 29 & $59.2 \%$ \\
\hline Crafts & 26 & $53.1 \%$ \\
\hline Cheese & 20 & $40.8 \%$ \\
\hline Cider & 20 & $40.8 \%$ \\
\hline Mushrooms & 18 & $36.7 \%$ \\
\hline Maple syrup & 16 & $32.7 \%$ \\
\hline Other dairy & 10 & $20.4 \%$ \\
\hline Wool & 7 & $14.3 \%$ \\
\hline Wine & 3 & $6.1 \%$ \\
\hline \multicolumn{3}{|l|}{ Other $^{2}$} \\
\hline Barbecue & 3 & $6.1 \%$ \\
\hline Artwork & 2 & $4.1 \%$ \\
\hline $\begin{array}{l}\text { Beverages } \\
\quad \text { (coffee, juice) }\end{array}$ & 2 & $4.1 \%$ \\
\hline \multicolumn{3}{|l|}{ Services } \\
\hline Public restrooms & 30 & $61.2 \%$ \\
\hline Handwashing facilities & 26 & $53.1 \%$ \\
\hline Musical festivals & 22 & $44.9 \%$ \\
\hline Picnic area(s) & 19 & $38.8 \%$ \\
\hline $\begin{array}{l}\text { Cooking } \\
\quad \text { demonstration(s) }\end{array}$ & 19 & $38.8 \%$ \\
\hline Concession stand(s) & 13 & $26.5 \%$ \\
\hline Petting zoo & 2 & $4.1 \%$ \\
\hline Other $^{2}$ & & \\
\hline $\begin{array}{l}\text { Unidentified special } \\
\text { events }\end{array}$ & 6 & $12.2 \%$ \\
\hline
\end{tabular}

Responses do not add to $100 \%$ because multiple responses were allowed.

${ }^{\mathrm{z}}$ Only products with multiple responses were reported.

Table 3. Two-stage least square model for vendor participation in Indiana's farmers' markets.

\begin{tabular}{lcrc}
\hline Variable & Estimate & \multicolumn{1}{c}{ SE } & $P$ value \\
\hline Intercept & 5.8080 & 10.2314 & 0.5746 \\
Years & 0.0947 & 0.1880 & 0.6183 \\
Rules & -0.7813 & 7.5941 & 0.9188 \\
Pay & $0.8738^{*}$ & 0.1968 & 0.0001 \\
No. of customers & $0.0873^{* *}$ & 0.0386 & 0.0439 \\
No. of services & 3.0079 & 2.3487 & 0.2105 \\
Reason 1 & -9.4997 & 8.4994 & 0.2729 \\
Reason 2 & -0.0940 & 1.5953 & 0.9534 \\
\hline
\end{tabular}

Adjusted $R^{2}=0.4374$

"Significant at the 0.01 level.

${ }^{* *}$ Significant at the 0.05 level. indicating the number of vendors increase by 0.0873 for every increase of one customer. In other words, holding all other variables constant for every 100-customer increase, the number of vendors would increase by eight.

The customer model. The dependent variable for the customer model (Eq. 2) was "number of customers," which was the market masters analysis of the average number of customers that visited the market each week in 2006.

No. of customers $=\beta_{0}+\beta_{1}$ WIC

$$
\begin{aligned}
& +\beta_{2} \text { days open } \\
& +\beta_{3} \text { No. of vendorshat } \\
& +\beta_{4} \text { No. of products } \\
& +\beta_{5} \text { concession stand } \\
& +\beta_{6} \text { live music } \\
& +\beta_{7} \text { cooking demonstration } \\
& +\beta_{8} \text { picnic area }+\beta_{9} \text { Reason } 1 \\
& +\beta_{10} \text { Reason } 2+\epsilon
\end{aligned}
$$

"WIC" was the first independent variable and was a dummy variable that represented the absence or presence of the Women Infant \& Children Farmers' Market Nutrition Program (FMNP). If the market accepted WIC, it was coded 1; otherwise, it was coded 0 . "Days open" was a variable measuring the number of days per week that a market was open. The vendor variable was count data, in which every vendor was identified per market for the 2006 season. The fourth variable was "number of products" in which market masters were asked to identify which products were available at their market from a list. Variables (5) concession stand, (6) live music, (7) cooking demonstration, and (8) picnic area were dummy variables. If the market master indicated the service was present at one farmers' market during the season, the service was coded with a 1 ; otherwise, it was coded as 0 . The ninth and tenth variables, Reason 1 and Reason 2, are the same as variables six and seven included in Eq. 1. Descriptive statistics are shown in Tables 1 and 2.

Each independent variable in Eq. 2 is expected to have a positive sign. The acceptance of WIC-FMNP vouchers should pro- vide a larger customer base because the households that receive WIC vouchers have nutritional needs related to fresh fruits and vegetables but have a lower income than generally associated with farmers' market customers (Fried, 2005). Accepting vouchers from the WIC program allows lower-income families to purchase fresh produce from the market, because without the FMNP program assistance, these customers would not shop at the market. Therefore, acceptance of WIC vouchers allows an additional segment of the population to participate in farmers' markets.

The "days open" variable is expected to have a positive impact on the number of customers. When the market is open multiple days per week, customer attendance should increase for two reasons. First, the same customer base visiting the market multiple times per week would increase the number of customers per week. Second, when the market is open multiple days per week, it may become more convenient for more shoppers, therefore increasing the number of customers per week. The number of vendors and products is expected to have a positive effect on the number of customers because as the product assortment increases, the number of choices provided to customers also increases.

Activities provided at the market such as concession stands, live music, cooking demonstrations, and picnic areas are expected to have a positive effect on the number of customers, because the festival atmosphere provided by these activities tends to attract customers (O’Neil, 2005). Farmers' markets exist for three primary reasons: customers, vendors, or economic revitalization; each reason should promote and attract customers.

Table 4 contains the estimated coefficients, SES, and t-values for the customer model. The adjusted $R^{2}$ for Eq. 2 was $40.5 \%$. The results show the variables WIC, number of products, presence of live music, presence of cooking demonstrations, and Reason 2 (vendors) are significant at the 0.01 level. The presence of concession stands and presence of a picnic area are significant at the 0.10 level. The market's acceptance of WIC, number of products, presence of a concession stand, and presence of a cooking demonstration all have the expected positive impact on the number of customers who

Table 4. Two-stage least squares model for customer participation in Indiana's farmers' markets.

\begin{tabular}{lcrr}
\hline Variable & Estimate & \multicolumn{1}{c}{ SE } & $P$ value \\
\hline Intercept & -40.1624 & 80.4148 & 0.6217 \\
WIC & $20.1340^{*}$ & 4.8359 & 0.0003 \\
Days open & -0.6215 & 21.0148 & 0.9766 \\
No. of vendors & 1.2935 & 1.1331 & 0.2641 \\
No. of products & $20.3775^{*}$ & 4.3321 & $<0.0001$ \\
Concession stand & $109.8765^{* * *}$ & 57.5481 & 0.0637 \\
Live music & $-198.9070^{*}$ & 67.2321 & 0.0065 \\
Cooking demonstration & $199.2977^{*}$ & 63.9105 & 0.0044 \\
Picnic area & $-104.5920^{* *}$ & 55.6714 & 0.0706 \\
Reason 1 & 4.9537 & 51.6714 & 0.9244 \\
Reason 2 & $-134.8310^{*}$ & 30.7422 & 0.0002 \\
\hline
\end{tabular}

Adjusted $R^{2}=0.4051$

"Significant at the 0.01 level.

${ }^{* *}$ Significant at the 0.05 level.

${ }^{* * * *}$ Significant at the 0.10 level 
attend the market. When WIC vouchers are accepted at a market, the number of customers increases by 20 . For every one additional product type available at the market, the number of customers increases by 20 per week when all other variables are held constant.

The presence of extra services has a mixed effect on the number of customers. The presence of a concession stand increases the number of customers by 110 per week. The presence of live music decreases the number of customers by almost 200 customers, whereas the presence of a cooking demonstration increases the number of customers by almost 200 per week. Picnic areas decreased the number of customers by $\approx 105$ customers per week.

Reasons 1 (customers) and Reason 2 (vendors) are included in the regression with Reason 3 (economic revitalization) as a reference in the intercept, $\beta_{0}$. The results show that if two markets were identical, except for the reason that the market existed, the market that existed for Reason 2 (vendors) would have 135 fewer customers than the market that existed for Reason 3 (economic revitalization).

\section{Discussion}

A two-stage least squares model was estimated to determine the factors that influenced the number of vendors and customers at farmers' markets. In Eq. 1, paying fees and the number of customers present were the two variables that had a significant, positive influence on vendor participation in a farmers' market. In Eq. 2, the presence of WIC, number of products available, the absence or presence of live music, absence or presence of cooking demonstrations, and Reason 2 (vendors) were significant at the 0.01 level. The absence or presence of concession stands and picnic areas were significant at the 0.10 level.

Two variables, number of customers and pay, were significant in the vendor model. This result is not surprising given these two variables indicate all revenue and a portion of the expenses that will influence the vendor's gross income. It was interesting that none of the other variables included in the model attribute to farmers vending at the farmers' market. Marr and Gast (1989), NYFMF (2005), and O'Neil (2005) found years the market had been operating and the presence of rules contribute to the market's stability. However, vendors may not find them important because they do not directly attribute these factors to gross income.

The adjusted $R^{2}$ for the vendor model was $43 \%$. Additional explanatory power may be linked to some nontangible aspects of farmers' markets such as a larger customer base, personal interaction with consumers, a better profit margin, convenience, and because it is the best or only market channel available (Capstick, 1982; Estes, 1985; Govindasamy et al., 1998a). These additional variables may have given the model more explanatory power; however, the market master provided the data collected in this study. These other variables could be collected for each vendor.

The customer model found WIC, number of products, concession stands, live music, cooking demonstrations, picnic area, and Reason 2 (markets run specifically for vendors as a way to sell their products) as variables that impact the number of customers. The acceptance of WIC, number of products, presence of a concession stand, and presence of a cooking demonstration all have a positive impact on the number of customers visiting farmers' markets per week, which was expected; whereas live music and picnic area had a negative effect on the number of customers.

When a market accepted WIC vouchers, the number of customers per week increased by 20 . This increase was expected, because the acceptance of WIC allows the customer base to expand to include lower-income women attracting a market segment beyond the typical farmers' market consumer. Research has shown the typical farmers' market consumer is a white woman, 45 to 64 years of age, and a college graduate with an income of $\$ 60,000$ or above (Eastwood et al., 1995; Govindasamy et al., 1998b). The results showed that as the number of product types increased, the number of customers per week increased by 20 . This result supported a previous study's finding that offering more products was one way to strengthen a market (Henneberry and Augustini, 2002).

The customer model found two unforeseen results. The presence of live music and picnic areas decreased the number of customers. These findings could indicate that customers attend the market to shop, not to be entertained. Some customers may find live music to be a distraction or unneeded background noise while they are interacting with vendors and friends. Some customer segments might avoid the market as a result of the perception that there would be a larger crowd because of the addition of live music. Because many customers cited the relationship with vendors as a reason for shopping at the farmers' market (Eastwood et al., 1995; Govindasamy et al., 1998b), they may feel this relationship is compromised when music is added. The type of music could also affect why customer participation decreased as a result of different consumer taste in music. Picnic areas may deter customers if the area is not well kept. Even when ample trash receptacles are available, there may be remnants of food. Food trails are notorious for attracting bees, flies, and ants, which would deter customers.

We asked market masters to specify the primary reason for the market's existence from these three options: 1) to offer customers access to local products; 2) to provide farmers an outlet for their products; or 3) to bring economic activity to the area. If two markets were identical, except for the reason that the market existed, the market that existed for Reason 2 (vendors) would have 135 fewer customers than the market that existed for Reason 3 (economic revitalization). One explanation of this finding could be based on the experience of the organizing group. Markets that are organized for economic activity (Reason 3 ) are typically created and funded by a government entity. This organization usually has someone with marketing experience; therefore, the promotional methods used by economic revitalization markets may be more effective at informing and/or attracting customers. Farmers organize a vendor-driven market (Reason 2). Historically, farmers spend their time doing what they know best: planning, growing, and harvesting crops. Traditionally, farmers leave the marketing and processing to other agribusinesses (Gale, 1997). Therefore, these markets may not be as well publicized and attractive to customers as markets that are created for other reasons. Another explanation for the increased number of customers at economic revitalization markets is these markets focus on attracting customers not only to the farmers' market, but also to the downtown or business district where the market is located. Meanwhile, farmers generally grow what they want or are capable of growing. However, this is not always what the customers want or need. Some farmers' markets are held in a city or county park, at the county fair grounds, or on property owned by a vendor. These locations may have adequate facilities but may not be the most convenient location for customers, because they are often on the outer edge of town.

Limitations. The limitation of this research includes the limited number of responses given the small population size. Overall, there were 80 farmers' markets found in Indiana. The number of responses was small because of the small sample size. To combat the small population size, the study was conducted as a census, meaning all known farmers' markets were included in the study. Forty-nine usable questionnaires were received for a final response rate of $61.3 \%$.

The adjusted $R^{2}$ for the customer model showed an adequate but not great fit for the data. The literature provided insight to additional factors that customers cited for shopping at farmers' markets, including the quality of produce, price of products, convenience of the market location, social enjoyment, and community support (Anderson et al., 1993; Govindasamy et al., 1998b; Roth, 1999). These additional variables may have given the model more explanatory power.

\section{Literature Cited}

Agricultural Marketing Service. 2006. Farmers market growth [electronic version]. $12 \mathrm{Jan}$. 2006. <http://www.ams.usda.gov/farmersmar kets/FarmersMarketGrowth.htm>.

Anderson, J., R. Smoley, N. Morris, Jr., and E. Bragg. 1993. Regional farmers' markets: A marketing and design study conducted for Springfield and Colombia, MO. U.S. Department of Agriculture, Wholesale and Alternative Markets Program, Washington, DC. 
Capstick, D. 1982. A study of direct marketing of farm produce in Arkansas (Bulletin 861). Agricultural Experiment Station, University of Arkansas, Fayetteville, AR.

Churchill, Jr. G. and D. Iacobucci. 2002. Marketing research methodological foundations. Harcourt College Publishers, Ft. Worth, TX.

Dillman, D. 2000. Mail and Internet surveys: The tailored design method. John Wiley \& Sons, New York, NY.

Eastwood, D., J. Brooker, and M. Gray. 1995. An intrastate comparison of consumers' patronage of farmers' markets in Knox, Madison, and Shelby counties (Bull. 95-03). Agriculture Experiment Station, University of Tennessee, Knoxville, TN.

Estes, E. 1985. Community farmers' markets in North Carolina: A study of consumers and sellers in 1981. U.S. United States Department of Agriculture, Agricultural Research Service, Washington, DC, and North Carolina State University, Raleigh, NC.

Fried, B. 2005. Farmers' markets boost the prospects of low-income communities with fresh, wholesome food. Making Places Newsletter, October [electronic version]. 3 May 2007. $<$ http://www.pps.org/info/newsletter/october 2005/markets_health>.
Gale, F. 1997. Farm-to-consumer direct marketing as a rural development tool. Rural Development Perspectives 12:19-25.

Govindasamy, R., M. Zurbriggen, J. Italia, A. Adelaja, P. Nitzsche, and R. VanVranken. 1998a. Farmers' markets: Producers characteristics and status of their businesses (P-021376-98). New Jersey Agriculture Experiment Station, Cook College, Rutgers.

Govindasamy, R., M. Zurbriggen, J. Italia, A Adelaja, P. Nitzsche, and R. VanVranken. 1998b. Farmers' markets: Consumer trends, preferences, and characteristics (P-02137-798). New Jersey Agriculture Experiment Station, Cook College, Rutgers.

Griffiths, W.E., R.C. Hill, and G.G. Judge. 1993. Learning and practicing econometrics. John Wiley and Sons, Inc., New York, NY.

Henneberry, S. and H. Augustini. 2002. Highlights of a farmers' market consumers' and producers' survey results. Department of Agricultural Economics, Oklahoma State University, Stillwater, OK.

Marr, C. and K. Gast. 1989. A guide to starting, operating, and selling in farmers' markets. Cooperative Extension Service, Kansas State University, Manhattan, KS.

New York Farmers' Market Federation (NYFMF). 2005. 10 principles of a successful farmers'- market [electronic version]. 11 Apr. 2007. $<$ http://www.nyfarmersmarket.com/pdf_files/ marketprinciples.pdf $>$.

O'Neil, D. 2005. Ten qualities of successful public markets. Making Places Newsletter, October [electronic version]. 3 May 2007. <http://www.pps.org/ info/newsletter/october2005/ten_characteristics $>$.

Payne, T. 2000. U.S. farmers markets -2000 a study of emerging trends. U.S. Department of Agriculture, Marketing and Regulatory Programs, Washington, DC.

Roth, M. 1999. Overview of Farm Direct Marketing Industry Trends. Paper presented at Agricultural Outlook Forum. 22 Feb.

Severson, K. 2006. Why roots matter more. New York Times. Nov. 15:G1.

Shaffer, J. and B. Cox. 2006. USDA Releases New Farmers' Market Statistics. U.S. Department of Agriculture, Agricultural Marketing Service, Washington, DC.

U.S. Department of Agriculture. 2006. Agricultural Marketing Service, Washington, DC. Farmers market facts, who benefits from farmers markets? [electronic version]. 27 Jan. 2006. <http:// www.ams.usda.gov/farmersmarkets/farmers marketbenefits.htm $>$.

Wilmont, F. 2006. Inside the data center. State Data Center, Indiana State Library. 